dictions of the formula are accurate within $\pm 2 \mathrm{kcal} / \mathrm{mol}$. Even complexes of a delocalized carbanion can be accomodated with a small correction of $-3 \mathrm{kcal} / \mathrm{mol}$. However, not surprisingly, the formula is not useful for complexes that are not properly hydrogen bonned, such as carbanions bonded to aprotic molecules.

After $\Delta \Delta H^{\circ}{ }_{\text {acid }}$ relations are accounted for, the intrinsic hydrogen-bonding strengths of proper carbanions, i.e., carbanions without heteroatoms, to protic solvent molecules are weaker by 4-8 $\mathrm{kcal} / \mathrm{mol}$ than for carbanions with electronegative oxygen or nitrogen functions. In the latter, experimental trends are consistent with ab initio calculations, indicating that the hydrogen-donor bonds to the electronegative heteroatom.
In $\mathrm{c}-\mathrm{C}_{5} \mathrm{H}_{5}{ }^{-}$and $\mathrm{c}-\mathrm{C}_{4} \mathrm{H}_{4} \mathrm{~N}^{-}$, trends in complexing energies suggest that the anionic aromatic $\pi$ systems can serve as electron donors to protic and possibly to aprotic hydrogen-bonding ligands.

Acknowledgment. This work was funded in part by a grant from the U.S. Department of Energy Office of Basic Energy Sciences.

Registry No. $\mathrm{HC} \equiv \mathrm{C}^{-}, 29075-95-4 ; \mathrm{CN}^{-}, 57-12-5 ;{ }^{-} \mathrm{CH}_{2} \mathrm{CN}, 21438-$ 99-3; ${ }^{-} \mathrm{CH}_{2} \mathrm{CHO}, 64723-93-9 ; \mathrm{CH}_{3} \mathrm{COCH}_{2}^{-}, 24262-31-5 ; \mathrm{CF}_{3} \mathrm{COCH}_{2}^{-}$, 64723-97-3; c- $\mathrm{C}_{5} \mathrm{H}_{5}^{-}, 12127-83-2 ; \mathrm{c}_{-}-\mathrm{C}_{4} \mathrm{H}_{4} \mathrm{~N}^{-}, 23303-09-5 ; \mathrm{H}_{2} \mathrm{O}, 7732-$ 18-5; $\mathrm{CH}_{3} \mathrm{OH}, 67-56-1 ; t-\mathrm{BuOH}, 75-65-0 ; \mathrm{C}_{6} \mathrm{H}_{5} \mathrm{CH}_{2} \mathrm{OH}, 100-51-6$; $\mathrm{CH}_{3} \mathrm{CH}_{2} \mathrm{OH}, 75-89-8 ; \mathrm{CH}_{3} \mathrm{CN}, 75-05-8 ; \mathrm{CD}_{3} \mathrm{CN}, 2206-26-0 ; \mathrm{CH}_{3} \mathrm{CO}-$ $\mathrm{CH}_{3}, 67-64-1 ; \mathrm{c}-\mathrm{C}_{4} \mathrm{H}_{4} \mathrm{NH}, 109-57-7 ; \mathrm{c}-\mathrm{C}_{5} \mathrm{H}_{6}, 542-92-7$.

\title{
Distonic Ions as Reacting Species ${ }^{\dagger}$
}

\author{
Thomas Bjørnholm, ${ }^{\ddagger}$ Steen Hammerum, ${ }^{*}$ and Dietmar Kuck ${ }^{\S}$ \\ Contribution from the Department of General and Organic Chemistry, University of Copenhagen, \\ The H. C. Ørsted Institute, Universitetsparken 5, 2100 Copenhagen Ø, Denmark, and the \\ Universität Bielefeld, Fakultät für Chemie, D-4800 Bielefeld 1, West Germany. \\ Received November 16, 1987
}

\begin{abstract}
The characteristic reactions of a family of distonic radical cations show that the gas-phase chemistry of these species differs considerably from that of the isomeric conventional molecular ions. Fifteen distonic radical cations, derived from - $\mathrm{CH}_{2} \mathrm{CH}_{2} \mathrm{NH}_{3}{ }^{+}$by introduction of alkyl substituents at $\mathrm{C}$ or $\mathrm{N}$, have been demonstrated to be stable species whose reactions are characteristic of their structure. The predominant fragmentation and isomerization processes are the following: (i) simple cleavage of a $\mathrm{C}-\mathrm{N}$ bond with formation of alkene ions or alkene molecules, (ii) 1,2-migration of protonated amino groups, and (iii) formation of ammonium ions by elimination of alkenyl radicals. Chain length permitting, these reactions may be preceded or accompanied by specific intramolecular hydrogen abstraction reactions, which lead to isomeric distonic ions with characteristically different reactions. The hydrogen abstraction reactions are generally reversible; in the presence of long alkyl groups isomerization to amine molecular ions (et vice versa) can occur. Correspondingly, the reactions of many low-energy amine molecular ions require isomerization to distonic intermediates prior to fragmentation.
\end{abstract}

A considerable number of recent papers have demonstrated the existence in the gas phase of stable distonic radical cations, ${ }^{1-14}$ and distonic ions are with increasing frequency being suggested as key intermediates in unimolecular fragmentation reactions. ${ }^{2,15-22}$ The collision-induced reactions of these species have often been used to establish their structural integrity, but the question of how the particular properties of distonic ions influence their reactions has not been addressed in the literature. We have studied the isomerization and dissociation reactions of a family of distonic amine ions, in order to discover the characteristic reactions of these species and to examine the difference between these reactions and those of the corresponding conventional molecular ions.

The term distonic ion was coined by Radom and co-workers ${ }^{23}$ to describe radical cations arising (formally) by ionization of zwitterions or diradicals. The difference between the properties of stable distonic ions and those of conventional molecular ions generated by direct ionization of neutral molecules can be considerable, and Radom's neologism has rapidly gained acceptance among gas-phase ion chemists. However, the properties of distonic ions often vary with the number of heavy atoms separating the charge and radical bearing sites. In the present paper we employ the adjectives $\alpha$-distonic, $\beta$-distonic, $\gamma$-distonic, etc., to denote respectively species with charge and radical at adjacent atoms $(\alpha$-distonic ions or ylidions, e.g., 1), with charge and radical separated by one heavy atom ( $\beta$-distonic ions, e.g. 2), by two heavy atoms ( $\gamma$-distonic ions), etc.

${ }^{\dagger}$ Presented in part at the 10 th International Mass Spectrometry Conference, Swansea (GB), Sept 9-13, 1985; Adv, Mass Spectrom. 1985, 787 - Address correspondence to this author at the University of Copenhagen.

University of Copenhagen.

1 Universität Bielefeld.
Chart I

$$
\begin{aligned}
& \mathrm{CH}_{3} \mathrm{NH}_{2}^{* *} \quad \mathrm{CH}_{3} \mathrm{CH}_{2} \mathrm{NH}_{2}^{+*} \\
& \mathrm{CH}_{2} \mathrm{NH}_{3}^{+} \quad \mathrm{CH}_{2} \mathrm{CH}_{2} \mathrm{NH}_{3}^{+}
\end{aligned}
$$$$
1
$$

Recent experimental and $a b$ initio studies ${ }^{11-14,21,24,25}$ of the various $\mathrm{CH}_{5} \mathrm{~N}^{\circ+}$ and $\mathrm{C}_{2} \mathrm{H}_{7} \mathrm{~N}^{++}$isomers have shown that $\alpha$ - and

(1) Schwarz, H. Shitsuryo Bunseki 1984, 32, 3,

(2) Hammerum, S. Mass Spectrom. Rev. 1988, 7, 123

(3) Bouma, W. J.; Macleod, J. K.; Radom, L. J. Chem. Soc., Chem. Commun. 1978, 724. Baumann, B. C.; MacLeod, J. K. J. Am. Chem. Soc. 1981, 103, 6223. Bouma, W. J.; MacLeod, J. K.; Radom, L. J. Am. Chem. Soc. 1980, 102, 2246. Baumann, B. C.; MacLeod, J. K.; Radom, L. J. Am. Chem. Soc. 1980, 102, 7927.

(4) Crow, F. W.; Gross, M. L.; Bursey, M. M. Org. Mass Spectrom. 1981 16,309

(5) Terlouw, J. K.; Heerma, W.; Dijkstra, G. Org. Mass Spectrom. 1981, $16,326$.

(6) Bouma, W. J.; MacLeod, J. K.; Radom, L. J. Am. Chem. Soc. 1982, $104,2930$.

(7) Holmes, J. L.; Lossing, F. P.; Terlouw, J. K.; Burgers, P. C. J. Am. Chem. Soc. 1982, 104, 2931

(8) Apeloig, Y.; Ciommer, B.; Frenking, G.; Karni, M.; Mandelbaum, A.; Schwarz, H.; Weisz, A. J. Am. Chem Soc. 1983, 105, 2186. Holmes, J. L. Burgers, P. C.; Terlouw, J. K.; Schwarz, H.; Ciommer, B.; Halim, H. Org. Mass Spectrom. 1983, 18, 208.

(9) Weger, E.; Levsen, K.; Ruppert, I.; Burgers, P. C.; Terlouw, J. K. Org. Mass Spectrom. $1983,18,327$.

(10) Sack, T. M.; Cerny, R. L.; Gross, M. L. J. Am. Chem. Soc. 1985, 107, 4562

(11) Drewello, T.; Heinrich, N.; Maas, W. P. M.; Nibbering, N. M. M.; Weiske, T.; Schwarz, H. J. Am. Chem. Soc. 1987, 109, 4810. 
$\beta$-distonic ions such as $\mathbf{1}$ and $\mathbf{2}$ exist alongside their conventional counterparts and that there are high energy barriers toward interconversion. Distonic amine ions with charge and radical position further separated also exist in potential wells, but the energy barriers for isomerization to conventional amine molecular ions (et vice versa) are in these cases lower. ${ }^{14,21}$ Neutralization-reionization studies ${ }^{14}$ have shown that the $\mathrm{C}_{3} \mathrm{H}_{9} \mathrm{~N}^{{ }^{++}}$ion population that exists microseconds after electron ionization of propylamine is a mixture of ions with conventional and distonic structure (eq 1). Similar conclusions were reached in studies of other low molecular weight amines. ${ }^{14,20}$

$$
\mathrm{CH}_{3} \mathrm{CH}_{2} \mathrm{CH}_{2} \mathrm{NH}_{2}^{+} \rightleftharpoons \mathrm{CH}_{2} \mathrm{CH}_{2} \mathrm{CH}_{2} \mathrm{NH}_{3}^{*}
$$

In this study the experimental strategy has been to examine the reactions of a relatively large number of distonic ions, to study the characteristic properties of these species, rather than to examine the fragmentation of individual ions in great detail. In general, distonic ions have no corresponding stable neutral molecule. For this reason distonic ions cannot be produced by direct ionization of suitable precursor molecules but must be formed by isomerization or fragmentation processes. The distonic ions examined in the present study were generated in the mass spectrometer ion source by fragmentation of alkoxyalkylamine molecular ions, which react by loss of a neutral aldehyde or ketone (see eq 2 for an example). Alkoxyalkylamines were chosen as

$$
\begin{aligned}
& \mathrm{R}^{\prime} \mathrm{R}^{2} \mathrm{CHO}-\mathrm{CH}_{2} \mathrm{CH}_{2} \mathrm{~N}\left(\mathrm{CH}_{3}\right)_{2} \longrightarrow \mathrm{R}^{\prime} \mathrm{R}^{2} \mathrm{CO}-\mathrm{CH}_{2} \mathrm{CH}_{2} \mathrm{NH}^{+}\left(\mathrm{CH}_{3}\right)_{2}- \\
& R^{\prime} R^{2} \mathrm{CO}+\mathrm{CH}_{2} \mathrm{CH}_{2}{ }^{+} \mathrm{H}\left(\mathrm{CH}_{3}\right)_{2} \\
& R^{\prime}, R^{2}: \mathrm{C}_{6} \mathrm{H}_{5}, \mathrm{H}_{2}, \mathrm{CH}_{3}, \mathrm{CH}_{3}
\end{aligned}
$$

precursor molecules because they produce the distonic ions in high ion yield ${ }^{26}$ and because they can be readily tailored to yield specifically substituted or isotope labeled distonic ions. The target ions were separated from other ionic species by the magnetic (mass) analyzer of a double focusing mass spectrometer with

(12) Holmes, J. L.; Lossing, F. P.; Terlouw, J. K.; Burgers, P. C. Can. J. Chem. 1983, 61, 2305 . 893 .

(13) Hammerum, S.; Kuck, D.; Derrick, P. J. Tetrahedron Lett. 1984, 25 ,

(14) Wesdemiotis, C.; Danis, P. O.; Feng, R.; Tso, J.; McLafferty, F. W. J. Am. Chem. Soc. 1985, 107, 8059.

(15) Benoit, F. M.; Harrison, A. G.; Lossing, F. P. Org. Mass Spectrom. 1977, 12, 78. Vajda, J. H.; Harrison, A. G.; Hirota, A.; McLafferty, F. W. J. Am. Chem. Soc. 1981, 103, 36. Wesdemiotis, C.; Csencsits, R.; McLafferty, F. W. Org. Mass Spectrom. 1985, 20,98. Burgers, P. C.; Holmes, J.

L.; Hop, C. E. C. A.; Terlouw, J. K. Org. Mass Spectrom. 1986, 21,549

(16) Biermann, H. W.; Morton, T. H. J. Am. Chem. Soc. 1983, 105, 5025. Eckart, K.; Zummack, W.; Schwarz, H. Org. Mass Spectrom. 1984, 19, 642. Wesdemiotis, C.; Feng, R.; McLafferty, F. W. J. Am. Chem. Soc. 1985, 107 , 715. Bowen, R. D.: Maccoll. A. J. Chem. Soc., Perkin Trans. 2 1987, 1019. Yates, B. F.; Bouma, W. J.; MacLeod, J. K.; Radom, L. J. Chem. Soc., Chem. Commun. 1987, 204.

(17) Weiske, T.; Schwarz, H. Chem. Ber. 1983, 116, 323. Göksu, E.; Weiske, T.; Halim, H.; Schwarz, H: J. Am. Chem. Soc. 1984, 106, 1167 McAdoo, D. J.; Hudson, C. E.; Zwinselman, J. J.; Nibbering, N. M. M. J. Chem. Soc., Perkin Trans. 2 1985, 1703. Weiske, T.; Halim, H.; Schwarz. H. Chem. Ber. 1985, 118, 495 .

(18) Audier, H. E.; Denhez, J. P.; Milliet, A.; Sozzi, G. Can. J. Chem 1984, 62, 931 . Audier, H. E.; Sozzi, G.; Denhez, J. P. Tetrahedron 1986, 42 , 1179.

(19) Audier, H. E.; Tabet, J. C. Org. Mass Spectrom. 1985, 20, 313. Hammerum, S.; Ingemann, S.; Nibbering, N. M. M. Org. Mass Spectrom. 1985, 20, 314. Vulpius, T.; Hammerum, S.; Bensimon, M.; Houriet, R.; Ingemann, S.; Nibbering, N. M. M. Adv. Mass Spectrom. 1985, 785.

(20) Hammerum, S.; Derrick, P. J. J. Chem. Soc., Perkin Trans. 21986. 1577

(21) Yates, B. F.; Radom, L. J. Am. Chem. Soc. 1987, 109, 2910.

(22) Bouchoux, G. Mass Spectrom. Rev. 1988, 7, 1.

(23) Yates, B. F.; Bouma, W. J.; Radom, L. J. Am. Chem. Soc. 1984, 106. 5805. Radom, L.; Bouma, W. J.; Nobes, R. H.; Yates, B. F. Pure Appl. Chem. 1984, 56, 1831.

(24) Bouma, W. J.; Dawes, J. M.; Radom, L. Org. Mass Spectrom. 1983 18, 12. Yates, B. F.; Nobes, R. H.; Radom, L. Chem. Phys. Lett. 1985, 116 , 474. Yates, B. F.; Bouma, W. J.; Radom, L. Tetrahedron 1986, 42, 6225.

(25) Yates, B. F.; Radom, L. Org. Mass Spectrom. 1987, 22, 430.

(26) Eckhardt, G. Org, Mass Spectrom. 1979, 14, 31.

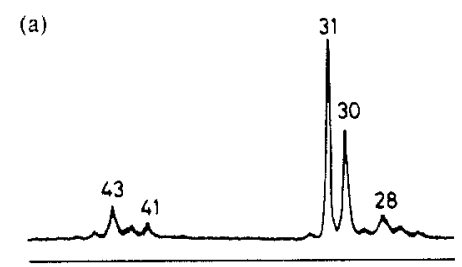

(b)

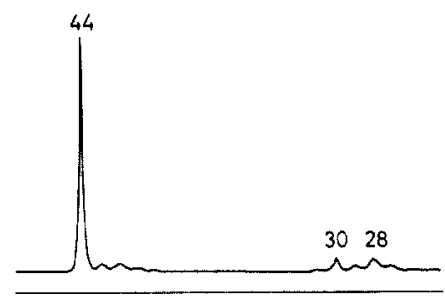

Figure 1. (a) $\mathrm{CID}$ spectrum of ${ }^{\circ} \mathrm{CH}_{2} \mathrm{CH}_{2}{ }^{+} \mathrm{NH}_{2} \mathrm{CH}_{3}$ (3) $(m / z$ 59). (b) CID spectrum of $\mathrm{CH}_{3} \mathrm{CH}_{2} \mathrm{NHCH}_{3}{ }^{+}$.

Scheme I. Characteristic Reactions of $\beta$-Distonic Ions Formation of ammonium ions

$$
\mathrm{CH}_{3} \dot{\mathrm{C}} \mathrm{HCH}_{2} \mathrm{NH}_{3}^{+} \longrightarrow \mathrm{CH}_{2}=\mathrm{CHCH}_{2}^{+}+\mathrm{NH}_{4}^{+}
$$

Loss of an alkene molecule

$$
{ }^{\circ} \mathrm{CH}_{2} \mathrm{CH}_{2} \stackrel{+}{\mathrm{N}} \mathrm{H}_{2} \mathrm{CH}_{3}-\mathrm{CH}_{2}=\mathrm{CH}_{2}+\mathrm{CH}_{3} \mathrm{NH}_{2}^{+\cdot}
$$

1,2-Migration of the protonated amino group

$$
\begin{array}{lc}
\mathrm{CH}_{3} & \mathrm{CH}_{3} \\
{ }^{+}-\mathrm{CH}_{2}-\mathrm{NH}_{3}^{+}=\stackrel{+}{\mathrm{N}} \mathrm{I}_{3}-\mathrm{C}_{3}-\mathrm{CH}_{2} \\
\mathrm{CH}_{3} & \mathrm{CH}_{3}
\end{array}
$$

Hydrogen abstraction reactions, leading to other $\alpha-, \beta-, \gamma-$, etc., distonic ions

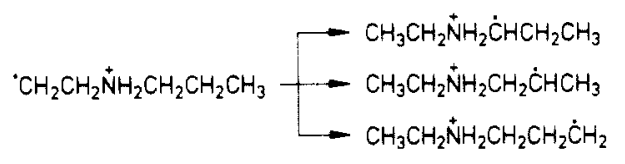

reversed geometry. The spontaneous and collision-induced reactions were studied in the field-free region between the magnetic and electric sectors.

Previous experimental studies have shown that the $\beta$-distonic ion ${ }^{\circ} \mathrm{CH}_{2} \mathrm{CH}_{2} \mathrm{NH}_{3}{ }^{+}$(2) is formed from 2-alkoxyethylamine molecular ions and that ion 2 can also be formed from a number of other precursors. ${ }^{12,13}$ Results presented by Eckhardt ${ }^{26}$ indicate that fragmentation of 2-alkoxyethylamines and 3-alkoxypropylamines in general yields $\beta$ - and $\gamma$-distonic ions. This is confirmed by the spontaneous and collision-induced reactions of the product ions examined in the present study. The identity of the ions has been further confirmed by isotope labeling and by comparison of the Collision Induced Dissociation spectra (CID spectra) of the distonic ions with the CID spectra of isomeric conventional molecular ions.

\section{Experimental Section}

Mass analyzed Ion Kinetic Energy spectra (MIKE spectra) and CID spectra were recorded on a ZAB-2F mass spectrometer (VG Analytical, Manchester, UK) under standard operating conditions (electron energy $70 \mathrm{eV}$, trap current $100 \mu \mathrm{A}$, accelerating voltage $6 \mathrm{kV}$, ion source temperature $180-190^{\circ} \mathrm{C}$, nominal ion source pressure $2-5 \times 10^{-7} \mathrm{Torr}$ ). Samples were introduced from a septum inlet heated to $150-200^{\circ} \mathrm{C}$. Spectra were recorded at both low and high ionizing energy, as a probe for the possible presence of mixtures of isobaric parent ions. ${ }^{27}$ Where two ions of the same nominal mass were present it was in most cases possible to suppress the ion of lower exact mass (probably oxygen con-

(27) Levsen, K. Fundamental Aspects of Organic Mass Spectrometry; Verlag Chemie: Weinheim 1978 
taining) by decreasing the ionization energy. In these cases MIKE and CID spectra recorded at low ionization energy ( $12 \mathrm{eV}$ nominal) were used for interpretation. In a few cases, contributions from isobaric ions were identified, and reference spectra were recorded and subtracted. Corrections for ${ }^{13} \mathrm{C}$ contributions from ions of mass $1 \mathrm{Da}$ less than the ion in question were applied after successive recordings of the spectra of the two neighboring ions under the same operating conditions. Corrections were performed by weighted subtraction of the spectra. CID spectra were obtained by collision with $\mathrm{He}$ in the 2 nd field-free region of the mass spectrometer. The collision gas pressure was adjusted so as to reduce the main beam intensity by $50 \%$.

The neutral precursors of the distonic ions 3-12, 15a, and 19 were obtained by reduction of the corresponding amides with $\mathrm{LiAlH}_{4}$ or $\mathrm{Li}$ AlD . The amides were prepared from isopropoxyacetic acid or 3-isopropoxypropionic acid by conventional methods. ${ }^{28}$ Reaction of ethyl chloroformate with 2-isopropoxyethylamine followed by reduction with $\mathrm{LiAlD}_{4}$ led to the precursor for 3a, and alkylation of 2-isopropoxy. ethylamine with $\mathrm{CD}_{3} \mathrm{I}$ gave the precursor for $11 \mathrm{a},{ }^{\circ} \mathrm{CH}_{2} \mathrm{CH}_{2}{ }^{+} \mathrm{NH}\left(\mathrm{CD}_{3}\right)_{2}$. O-Alkylation of $N$-(hydroxyalkyl)phthalimides in a Gabriel-type synthesis ${ }^{29}$ led to the precursors for ions 13-16, 18, and 20. Amines needed for reference purposes were obtained by reduction of the corresponding amides, if not commercially available. All precursors were identified by NMR and mass spectrometry and purified by preparative gas chromatography.

\section{Results and Discussion}

The spontaneous and collision-induced unimolecular reactions of the $\beta$-distonic ions studied are summarized as MIKE and CID spectra in Tables I and II; the equations in Scheme I exemplify the characteristic reactions.

The reactions of $\beta$-distonic ions are very different from those of the corresponding conventional molecular ions. The CID spectra of ${ }^{\circ} \mathrm{CH}_{2} \mathrm{CH}_{2}{ }^{+} \mathrm{NH}_{2} \mathrm{CH}_{3}$ (3) and $\mathrm{CH}_{3} \mathrm{CH}_{2} \mathrm{NHCH}_{3}{ }^{++}$ (Figure 1) illustrate a characteristic and general difference: the $\beta$-distonic ion reacts by cleavage of the $\mathrm{C}-\mathrm{N}$ bond, expelling $\mathrm{C}_{2} \mathrm{H}_{4}$, whereas the conventional ion undergoes $\mathrm{C}-\mathrm{C}$ cleavage, losing a methyl radical.

The spontaneous and collision-induced reactions of $\gamma$-distonic ions are, by contrast, very similar to the reactions of the corresponding conventional molecular ions ( $\alpha$-cleavage). However, small quantitative differences between the CID spectra as well as the results of isotope labeling experiments confirm the formation of $\gamma$-distonic ions from 3-alkoxypropylamines, corroborating previous results. ${ }^{13,14,26}$ For example, fragmentation of 3benzyloxypropylamine labeled at the benzylic positions leads to product ions incorporating one deuterium atom. The subsequent spontaneous reactions show that the itinerant deuterium has migrated to the nitrogen atom (eq 9).

$$
\begin{aligned}
& \mathrm{C}_{6} \mathrm{H}_{5} \mathrm{CD}_{2} \mathrm{OCH}_{2} \mathrm{CH}_{2} \mathrm{CH}_{2} \mathrm{NH}_{2}^{+*}-\overline{-\mathrm{C}_{6} \mathrm{H}_{5} \mathrm{CDO}^{-}}
\end{aligned}
$$

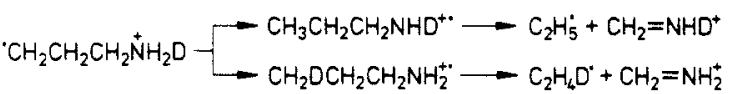

$$
\begin{aligned}
& \mathrm{m} / 231: \mathrm{m} / 2 \quad 30=5: 1
\end{aligned}
$$

Collision-Induced Reactions. The characteristic collision-induced reaction of $\beta$-distonic ions is cleavage of the $\mathbf{C}-\mathbf{N}$ bond, leading to alkene molecules (eq 10) or alkene radical cations (eq 11), the charge remaining on the fragment of lower ionization energy. $\mathrm{C}-\mathrm{N}$ cleavage is particularly important for small $\beta$-distonic ions with a limited number of alternative reaction pathways; the base peak in the CID spectra of many small $\beta$-distonic ions ( $3-5$ and 13-17) is due to formation of $\mathrm{RNH}_{2}{ }^{++}$or loss of $\mathrm{NH}_{3}$ (eq 10 and 11).

$$
\begin{aligned}
& \mathrm{CH}_{2} \mathrm{CH}_{2} \stackrel{+}{\mathrm{N}} \mathrm{H}_{2} \mathrm{R} \longrightarrow \mathrm{CH}_{2}=\mathrm{CH}_{2}+\mathrm{RNH}_{2}^{+\cdot} \\
& \left(\mathrm{CH}_{3} \mathrm{l}_{2} \dot{\mathrm{C}} \mathrm{CH}_{2} \mathrm{NH}_{3}^{+} \longrightarrow\left(\mathrm{CH}_{3}\right)_{2} \mathrm{C}=\mathrm{CH}_{2}^{+}+\mathrm{NH}_{3}\right.
\end{aligned}
$$

(28) Fuson, R. C.; Wojcik, B. H. Organic Syntheses; Wiley: New York, 1943; Collect. Vol. II, p 260. Reberg, C. E.; Dixon, M. B.; Fisher, C. H. J. Am. Chem. Soc, 1946, 68, 544.

(29) Sheehan, J. C.; Bolhofer, W. A. J. Am. Chem Soc, 1950, 72, 2786 Salzberg, P. L.: Supniewski, J. V. Organic Synthesis; Wiley: New York, 1932 Collect. Vol. I, p 119. Osby, J. O.; Martin, M. G.; Ganem, B. Tetrahedron Lett. 1984, 25, 2093.
The collision-induced alkene loss (eq 10) is an important and structurally significant reaction also for $\beta$-distonic ions with long $N$-alkyl substituents, even though the relative importance of alkene loss diminishes as the alkyl chain increases. In addition, these ions show a number of reactions initiated by intramolecular hydrogen abstraction (eq 6-8), which are also among the spontaneously occurring processes. The major difference between the MIKE and CID spectra in these cases consists in the peaks corresponding to ions resulting from collision-induced alkene loss. Cleavage of the carbon-heteroatom bond also gives rise to abundant ions in the collision-induced reactions of related distonic ions ${ }^{5,9}$ such as ${ }^{\circ} \mathrm{CH}_{2} \mathrm{CH}_{2} \mathrm{OH}_{2}{ }^{+}$and ${ }^{\circ} \mathrm{CH}_{2} \mathrm{CH}_{2} \mathrm{PH}_{3}{ }^{+}$.

Fragmentation of $\beta$-substituted neutral radicals is a well-described reaction, ${ }^{30}$ which is often reversible. Also the alkene elimination from $\beta$-distonic ions is reversible; the reverse process, addition of alkenes to amine radical cations, has been observed in bimolecular gas-phase reactions as well as in condensed phase. $^{2,19,31}$

Many small $\alpha$ - and $\beta$-distonic ions form doubly charged ions upon collision that show up as intense narrow peaks in the CID spectra. ${ }^{7,12,32}$ These peaks are not prominent for conventional molecular ions. ${ }^{33}$ Among the distonic ions examined in the present study only the ions without $\mathrm{N}$ substituents give rise to abundant doubly charged ions.

Spontaneous Unimolecular Reactions. Formation of Ammonium Ions. $\beta$-Distonic ions with a free $\mathrm{NH}_{3}{ }^{+}$group $(13-17)$ react with formation of ammonium ions, $\mathrm{NH}_{4}{ }^{+}$. This reaction proceeds specifically by transfer of a $\gamma$-hydrogen atom; in particular, fragmentation of the $\alpha$-labeled ion, $\left(\mathrm{CH}_{3}\right)_{2} \mathrm{CCD}_{2} \mathrm{NH}_{3}{ }^{+}(15 \mathrm{a})$, gives rise exclusively to unlabeled ammonium ions (eq 12). N-Substituted $\beta$-distonic ions form alkylammonium ions provided that $\gamma$-hydrogen atoms are available (eq 13). Analogously, $N, N$-dialkyl $\beta$-distonic ions give rise to $N, N$-dialkyl ammonium ions (e.g., $\mathrm{C}_{2} \mathrm{H}_{5}{ }^{+} \mathrm{NH}_{2} \mathrm{CH}_{3}$ is formed from 12 )

$$
\begin{aligned}
& \sum_{15 \mathrm{O}}^{\mathrm{H}} \mathrm{CD}_{2} \mathrm{NH}_{3}^{+} \longrightarrow-\mathrm{CD}_{2}^{+}+\mathrm{NH}_{4}^{+}
\end{aligned}
$$

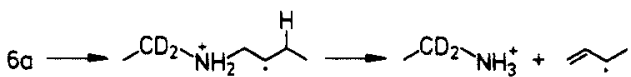

Alkene Loss. Spontaneous elimination of a neutral alkene molecule proceeds in high yield for $N, N$-dialkyl $\beta$-distonic ions. The most abundant product ion formed from ${ }^{\circ} \mathrm{CH}_{2} \mathrm{CH}_{2}{ }^{+} \mathrm{NH}$ $\left(\mathrm{CH}_{3}\right)_{2}(11)$ arises by loss of ethylene, and the homologous ion, 12, loses $\mathrm{C}_{5} \mathrm{H}_{10}$ after 1,5-hydrogen migration to give the second most abundant product ion. The fragmenting $\beta$-distonic ion is in this case formed by isomerization of the initial $\beta$-distonic ion prior to fragmentation, as shown in eq 14.

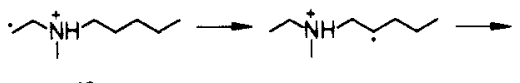

12

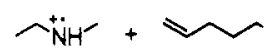

Alkene loss proceeds in lower yield for $\beta$-distonic amine ions with only one $N$-alkyl group (3-10), possibly owing to the higher energy requirements for formation of an alkene molecule and a primary amine radical cation. A more favorable reaction for the $N$-alkyl $\beta$-distonic ions is loss of an alkyl radical from the $\alpha$-distonic ion formed after 1,4-hydrogen atom transfer (eq 6; see also below). Spontaneous alkene loss is not observed for $\beta$-distonic ions with a free $\mathrm{NH}_{3}^{+}$group.

1,2-Migration of Protonated Amino Groups. A previous study ${ }^{13}$ has provided unambiguous experimental evidence for the occur-

(30) Nonhebel, D. C.; Walton, J. C. Free-Radical Chemistry; Cambridge University Press: Cambridge (UK), 1974.

(31) Chow, Y. L. Acc. Chem. Res. 1973, 6, 354. Chow, Y. L.; Danen, W. C.; Nelsen, S. F.; Rosenblatt, D. H. Chem. Rev. 1978, 78, 243.

(32) Burgers, P. C.; Holmes, J. L.; Terlouw, J. K.; van Baar, B. Org. Mass Spectrom. 1985, 20, 202

(33) Maquin, F.; Stahl, D.; Sawaryn, A.; von R. Schleyer, P.; Koch, W.; Frenking, G.; Schwarz, H. J. Chem. Soc., Chem. Commun. 1984, 504. 
MIKE
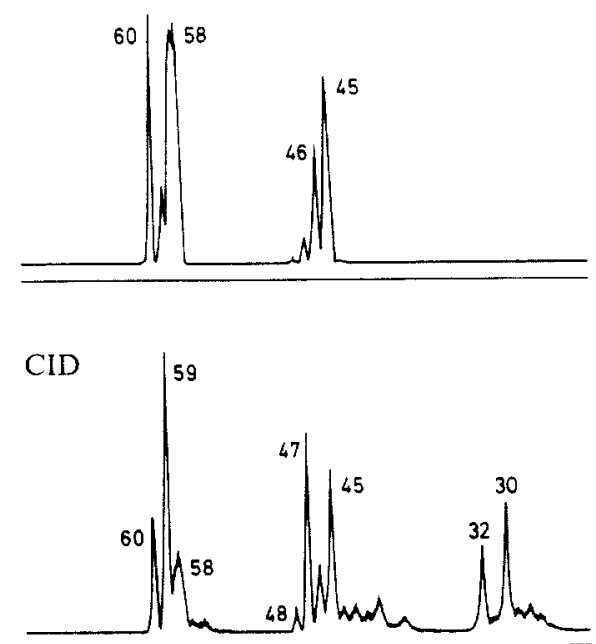

Figure 2. MIKE and CID spectra of ${ }^{\circ} \mathrm{CH}_{2} \mathrm{CD}_{2}{ }^{+} \mathrm{NH}_{2} \mathrm{CH}_{2} \mathrm{CH}_{2} \mathrm{CH}_{3}$ (5a) $\left(m / z\right.$ 89). $m / z$ 60: loss of $29\left(\mathrm{C}_{2} \mathrm{H}_{5}{ }^{\circ}\right)$ from $\mathrm{CH}_{3} \mathrm{CD}_{2} \mathrm{NHCH}_{2} \mathrm{CH}_{2} \mathrm{CH}_{3}{ }^{+4}$. $m / z$ 59: loss $30\left(\mathrm{CH}_{2}=\mathrm{CD}_{2}\right)$ from ${ }^{\circ} \mathrm{CH}_{2} \mathrm{CD}_{2}+\mathrm{NH}_{2} \mathrm{CH}_{2} \mathrm{CH}_{2} \mathrm{CH}_{3}$ primarily CID. $m / z$ 58: loss $31\left(\mathrm{CH}_{3} \mathrm{CD}_{2}{ }^{\circ}\right)$ from $\mathrm{CH}_{3} \mathrm{CO}_{2}$ ${ }^{+} \mathrm{NH}_{2} \mathrm{CHCH}_{2} \mathrm{CH}_{3}$ after a 1,4-H shift. $m / z$ 48: loss $41\left(\mathrm{C}_{3} \mathrm{H}_{5}{ }^{\circ}\right)$ from $\mathrm{CH}_{3} \mathrm{CD}_{2}{ }^{+} \mathrm{NH}_{2} \mathrm{CH}_{2} \dot{\mathrm{C}} \mathrm{CCH}_{3}$ after 1,5-H shift. $\mathrm{m} / z$ 47: loss $42\left(\mathrm{C}_{3} \mathrm{H}_{6}\right)$ from $\mathrm{CH}_{3} \mathrm{CD}_{2}{ }^{+} \mathrm{NH}_{2} \mathrm{CH}_{2} \dot{\mathrm{C}} \mathrm{CCH}_{3}$ after 1,5-H shift, primarily CID. $\mathrm{m} / \mathrm{z}$ 45: loss $44\left(\mathrm{C}_{3} \mathrm{H}_{6} \mathrm{D}^{*}\right)$ from $\mathrm{CH}_{3} \mathrm{CD}^{+} \mathrm{NH}_{2} \mathrm{CH}_{2} \mathrm{CH}_{2} \mathrm{CH}_{2} \mathrm{D}$ after two $\mathrm{H}$ shifts (probably 1,$6 ; 1,5$ ).

rence of reversible 1,2-migration of $\mathrm{NH}_{3}$ in ${ }^{\circ} \mathrm{CH}_{2} \mathrm{CH}_{2} \mathrm{NH}_{3}^{+}$(2). Early computational work $\mathrm{k}^{34}$ suggested that 1,2-migration of the amino group in 2-aminoethyl radicals should be facilitated by protonation, and recent calculations have placed the barrier for rearrangement in the protonated radical (i.e., 2) at $120 \mathrm{~kJ} / \mathrm{mol}$, which is below the calculated threshold for dissociation. ${ }^{25}$

Isomerization by 1,2-migration in 2-ammonioethyl radicals and in the analogous 2 -oxonioethyl radicals ( $\beta$-distonic ions) can be considered as models of some coenzyme $B_{12}$ induced isomerizations. The mechanism of these transformations has long been under dispute, ${ }^{35}$ but experimental work dealing with related systems supports the intermediacy of radical species. ${ }^{36}$

The reactions of the $C$-alkyl analogues of ${ }^{\circ} \mathrm{CH}_{2} \mathrm{CH}_{2} \mathrm{NH}_{3}{ }^{+}$(ions 13-17) show that $1,2-\mathrm{NH}_{3}$ migration occurs in general for $\beta$ distonic amine radical cations. The CID spectra of $\left(\mathrm{CH}_{3}\right)_{2} \dot{\mathrm{C} C H_{2}} \mathrm{NH}_{3}{ }^{+}(15)$ and ${ }^{\circ} \mathrm{CH}_{2} \mathrm{C}\left(\mathrm{CH}_{3}\right)_{2} \mathrm{NH}_{3}{ }^{+}(16)$ are indistinguishable within experimental error, demonstrating readily occurring interconversion (probably favoring 15 , see eq 5 ). Likewise, the CID spectra of $\mathrm{CH}_{3} \mathrm{CHCH}_{2} \mathrm{NH}_{3}^{+}$(13) and - $\mathrm{CH}_{2} \mathrm{CH}\left(\mathrm{CH}_{3}\right) \mathrm{NH}_{3}{ }^{+}$(14) are very similar (eq 15), but the presence of some structure-characteristic reactions indicate that the initial structure is retained for some of the nonreacting ions. In particular, the isomer with a free $\mathrm{CH}_{2}$ group, 14, suffers collision-induced loss of $\mathrm{CH}_{2}$ whereas 13 does not. The retention, for some ions, of the initial structure confirms that the barrier for interconversion by amino group migration is substantial, as predicted by calculation. ${ }^{25}$

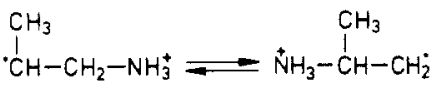

$$
\begin{aligned}
& 14
\end{aligned}
$$

The $\mathrm{N}$-alkyl analogues of ${ }^{\circ} \mathrm{CH}_{2} \mathrm{CH}_{2} \mathrm{NH}_{3}{ }^{+}$undergo a similar rearrangement, 1,2-migration of a protonated alkylamino group. The reactions of ${ }^{\circ} \mathrm{CH}_{2} \mathrm{CH}_{2}{ }^{+} \mathrm{NH}_{2} \mathrm{CH}\left(\mathrm{CH}_{3}\right)_{2}$ (9) provide an example. Expulsion of $\mathrm{C}_{2} \mathrm{H}_{5}{ }^{\circ}$ from 9 gives rise to a composite metastable peak (Figure 3 ), indicating that two different processes

(34) Golding, B. T.; Radom, L. J. Am. Chem. Soc. 1976, 98, 6331

(35) Abeles, R. H.; Dolphin, D. Acc. Chem. Res. 1976, 9, 114

(36) Halpern, J. Pure Appl. Chem. 1983, 55, 1059. Halpern, J. Science 1985, 227, 869. Wollowitz, S.; Halpern, J. J. Am. Chem. Soc. 1984, I06, 8319 .

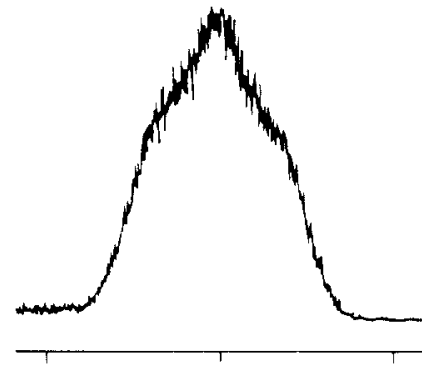

58

57

Figure 3. Enlargment of the $\mathrm{m} / z$ 58 peak in the MIKE spectrum of $-\mathrm{CH}_{2} \mathrm{CH}_{2}{ }^{+} \mathrm{NH}_{2} \mathrm{CH}\left(\mathrm{CH}_{3}\right)_{2}(9)$

resuit in loss of ethyl radicals. Examination of the reactions of the deuterium labeled analogue, ${ }^{\circ} \mathrm{CH}_{2} \mathrm{CD}_{2}{ }^{+} \mathrm{NH}_{2} \mathrm{CH}\left(\mathrm{CH}_{3}\right)_{2}(9 \mathrm{a})$, confirms this; loss of $\mathrm{C}_{2} \mathrm{H}_{5}{ }^{\circ}$ as well as $\mathrm{C}_{2} \mathrm{H}_{3} \mathrm{D}_{2}{ }^{\circ}$ is observed. The latter reaction occurs via an $\alpha$-distonic isomer formed by a $1,4-\mathrm{H}$ shift (cf. eq 18). Elimination of the unlabeled ethyl group requires a multistep isomerization involving 1,2-migration of the protonated alkylamino group within the the isopropyl group (eq 16). A closely analogous sequence of reactions precedes loss of $\mathrm{C}_{3} \mathrm{H}_{7}{ }^{\circ}$ from - $\mathrm{CH}_{2} \mathrm{CH}_{2}{ }^{+} \mathrm{NH}_{2} \mathrm{C}\left(\mathrm{CH}_{3}\right)_{3}(10)$, which does not possess a readily expelled $\mathrm{C}_{3}$ fragment.

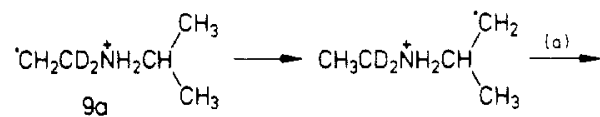

$$
\begin{array}{r}
\mathrm{CH}_{3} \mathrm{CD}_{2} \stackrel{+}{\mathrm{N}} \mathrm{H}_{2} \mathrm{CH}_{2} \dot{\mathrm{C}} \mathrm{HCH}_{3}-\stackrel{(b)}{-}-\mathrm{CH}_{3} \mathrm{CD}_{2} \stackrel{+}{\mathrm{N} H C H_{2}} \mathrm{CH}_{2} \mathrm{CH}_{3} \longrightarrow \\
\mathrm{CH}_{3} \mathrm{CO}_{2} \stackrel{*}{\mathrm{~N} H} \mathrm{CH}_{2}+\mathrm{C}_{2} \mathrm{H}_{5}
\end{array}
$$

(a) 1,2- $\mathrm{RNH}_{2}$ migration. (b) Successive 1,$5 ; 1,6$; and $1,4 \mathrm{H}$-shifts.

An important fragmentation of $\beta$-distonic ions with long $N$-alkyl chains is loss of an alkyl radical from the $\beta$-carbon atom in the $N$-alkyl group. The key step in this reaction is 1,2-migration of the amino group, which converts the $N$-alkyl substituent, $\mathrm{CH}_{2} \mathrm{CH}_{2} \mathrm{R}$, to a 1-methylalkyl group, $\mathrm{CH}\left(\mathrm{CH}_{3}\right) \mathrm{R}$; loss of the radical (R) is an $\alpha$-cleavage of the isomerized ion (eq 22). These reactions are discussed in more detail below.

The loss of $\mathrm{C}_{3} \mathrm{H}_{7} \cdot$ from ${ }^{\circ} \mathrm{CH}_{2} \mathrm{CH}_{2}+\mathrm{NH}\left(\mathrm{CH}_{3}\right) \mathrm{C}_{5} \mathrm{H}_{11}$ (12) shows that also 1,2-migration of protonated dialkylamino groups occurs, in competition with other low-energy reactions.

Intramolecular Hydrogen Abstraction. Many fragmentation reactions of $\beta$-distonic ions require initial isomerization by hydrogen atom abstraction, which converts $\beta$-distonic ions to isomeric distonic species (eq 6-8). The presence of these isomers, in particular of more than one $\beta$-distonic ion, is shown by the CID spectra (see below); the intermediacy of $\alpha$ - and $\gamma$-distonic isomers can be inferred from the unimolecular reactions of ions that are initially $\beta$-distonic species.

1,4-Abstraction of an $\alpha$-hydrogen atom from the $N$-alkyl chain of $N$-substituted $\beta$-distonic ions results in formation of an intermediate $\alpha$-distonic ion (eq 6), which expels an alkyl radical by simple cleavage of the $\mathrm{C}-\mathrm{N}$ bond ${ }^{37}$ (eq 17). For ${ }^{\circ} \mathrm{CH}_{2} \mathrm{CH}_{2}-$ ${ }^{+} \mathrm{NH}_{2} \mathrm{CH}_{3}(3)$ this process gives rise to the most abundant product ion. The reactions of the $\mathrm{CD}_{3}$ analogue (3a) (eq 17) show that the hydrogen abstraction is specific and apparently not readily reversible: one deuterium atom is transferred from the methyl group, accompanied by very little hydrogen/deuterium exchange. The $\alpha$-distonic intermediate is expected to be a stable species; however, it possesses considerable internal energy when formed via 1,4-hydrogen abstraction (see below) and therefore reacts rapidly by simple fission of the $\mathrm{C}-\mathrm{N}$ bond. Analogous behavior is observed for ions with longer $N$-alkyl groups $(4-6,9)$, that is, loss of $\mathrm{CH}_{3} \mathrm{CD}_{2}{ }^{-}$from the labeled ions $4 \mathrm{a}-6 \mathrm{a}$ and loss of $\mathrm{CH}_{3} \mathrm{CH}_{2}{ }^{*}$ from 9. A similar reaction was reported for the oxygen analogue, ${ }^{4}$ - $\mathrm{CH}_{2} \mathrm{CH}_{2}{ }^{+} \mathrm{OHCH}_{3}$; cleavage of the carbon-heteroatom bond in

(37) Hammerum, S. Acta Chem. Scand., submitted for publication. 
other $\alpha$-distonic ions has also been observed., , $^{832}$

The absence of $H / D$ exchange prior to alkyl loss from 3a indicates that the rate-limiting step is the hydrogen abstraction. and not the subsequent $\mathrm{C}-\mathrm{N}$ cleavage (eq 17). For the $N, N$ dialkyl analogue, ${ }^{\circ} \mathrm{CH}_{2} \mathrm{CH}_{2}{ }^{+} \mathrm{NH}\left(\mathrm{CD}_{3}\right)_{2}$ (11a), alkene loss is favored over alkyl loss by a factor of 20 . These reactions are likewise not accompanied by $\mathrm{H} / \mathrm{D}$ exchange $(m / z 51: 50: 49=20: 0: 1)$. The specific loss of $\mathrm{DCH}_{2} \mathrm{CH}_{2}{ }^{*}$ also from 11 a confirms that hydrogen abstraction is followed immediately by alkyl loss. This indicates that the competition between alkene and alkyl loss is governed by the relative rates of hydrogen abstraction and alkene loss, not by the heats of formation of the products, which are in all cases slightly lower for the alkyl loss (by $10-40 \mathrm{~kJ} / \mathrm{mol}$ ). ${ }^{38}$ The energy barrier for alkene loss from 3 and 11 can be estimated from the reaction thermochemistry to be 160 and $120 \mathrm{~kJ} / \mathrm{mol}$, respectively, plus any critical energy for the reverse reaction (the addition of an amine cation radical to an alkene). The energy barrier for 1,4-hydrogen abstraction must be less than that for alkene elimination, since alkyl loss competes successfully even though it has a tighter transition state. This is supported by studies showing that 1,4-hydrogen atom abstraction reactions in alkyl radicals ${ }^{39}$ have critical energies around $90 \mathrm{~kJ} / \mathrm{mol}$.

$$
\mathrm{CH}_{2} \mathrm{CH}_{2} \stackrel{+}{\mathrm{N}} \mathrm{H}_{2} \mathrm{CO}_{3} \longrightarrow \mathrm{DCH}_{2} \mathrm{CH}_{2} \stackrel{+}{\mathrm{N}} \mathrm{H}_{2} \dot{\mathrm{C}} \mathrm{O}_{2} \longrightarrow
$$$$
3 a
$$

$$
\mathrm{C}_{2} \mathrm{H}_{4} \mathrm{O}^{+}+\mathrm{CO}_{2}=\mathrm{NH}_{2}^{+}
$$

Loss of the alkyl group in reactions analogous to eq 17 often results in broad metastable peaks (see Figures 2 and 3 ), indicating an energy barrier for the reverse reaction $\left(T_{0.5}=10-20 \mathrm{~kJ} / \mathrm{mol}\right)$. The presence of this barrier could be taken to indicate a more complicated reaction pathway than simple cleavage of the $\alpha$-distonic ion. One possibility would be that 1,2-alkyl migration from nitrogen to carbon in the $\alpha$-distonic intermediate gives rise to a conventional amine molecular ion, for which alkyl radical loss (by $\alpha$-cleavage) is the expected reaction. 1,2-Alkyl migration from the heteroatom has been described for other $\alpha$-distonic ions, ${ }^{8}$ but reactions of this kind do not seem to take place for distonic amine ions; deuterium labeling demonstrates that the two ethyl groups in 5 a have not become equivalent prior to ethyl loss (eq 18). Either ethyl group may be expelled, but the shapes of the corresponding metastable peaks are strikingly different, indicating different fragmentation pathways (note the $\mathrm{m} / \mathrm{z} 58$ and 60 peaks in Figure 2 ). This strongly suggests that loss of the deuteriated ethyl group occurs directly by $\mathrm{C}-\mathrm{N}$ cleavage in the $\alpha$-distonic intermediate, while the unlabeled ethyl group is lost after isomerization to the corresponding secondary amine molecular ion (see below, eq 21). The presence of an energy barrier for the reverse reaction has been suggested to be a general phenomenon for alkyl radical loss from $\alpha$-distonic ions and related species. ${ }^{40}$

$$
\mathrm{C}_{2} \mathrm{H}_{3} \mathrm{O}_{2}^{+}+\mathrm{CH}_{3} \mathrm{CH}_{2} \mathrm{CH}=\mathrm{NH}_{2}^{+}
$$

(38) The heats of formation of the products formed from 3 and $\mathbf{1 1}$ are the following (in kJ/mol): $\mathrm{CH}_{2}=\mathrm{NH}_{2}^{+}, 744 ; \mathrm{CH}_{3} \mathrm{NH}_{2}{ }^{++}, 835 ; \mathrm{C}_{2} \mathrm{H}_{5}, 118 ; \mathrm{C}_{2} \mathrm{H}_{4}$ 53. Lossing. F. P.: Lam, Y.-T.: Maccoll, A. Can. J. Chem. 1981, 59, 2228. Aue, D. H.; Webb, H. M.; Bowers, M. T. J. Am. Chem. Soc. 1976, $98,311$. Schultz, J. C.; Houle, F. A.; Beauchamp, J. L. J. Am. Chem. Soc. 1984, 106 , 3917. Pedley, J. B.; Naylor, R. D.; Kirby, S. P. The thermodynamic data of organic compounds: Chapman and Hall: London, 1986.

(39) Larson, C. W.; Chua, P. T.; Rabinovitch, B. S. J. Phys. Chem. 1972 76, 2507. Watkins, K. W. Can. J. Chem. 1972, 50, 3738. Watkins, K. W. Lawson, D. R. J. Phys. Chem. 1971, 75, 1632.
Isomerization by 1,5 -hydrogen abstraction converts $N$-alkyl $\beta$-distonic ions to isomeric $\beta^{\prime}$-distonic species (eq 7 and 19). Either can react by $\mathrm{C}-\mathrm{N}$ cleavage, and loss of both alkene fragments are important collision-induced reactions for $4,5,9$, and 12 , demonstrating that isomerization proceeds efficiently prior to dissociation (eq 19; see also Figure 2). Reactions proceeding by way of 1,4-hydrogen abstraction are also observed for the $\beta \rightarrow$ $\beta^{\prime}$ isomerized species, as illustrated by the loss of the isopropyl group from ${ }^{\circ} \mathrm{CH}_{2} \mathrm{CH}_{2}{ }^{+} \mathrm{NH}_{2} \mathrm{CH}\left(\mathrm{CH}_{3}\right)_{2}$ (9) (eq 20). Loss of the isopropyl group from the labeled analogue ${ }^{\circ} \mathrm{CH}_{2} \mathrm{CD}_{2}{ }^{+} \mathrm{NH}_{2} \mathrm{CH}-$ $\left(\mathrm{CH}_{3}\right)_{2}(9 \mathrm{a})$ leads to ions of $\mathrm{m} / \mathrm{z} 45$ and 46 in approximately a $1: 1$ ratio. The transfer of either $H$ or $D$ shows that 1,2 -migration of the protonated amino group in the initial $\beta$-distonic ion can precede 1,5-hydrogen abstraction. Ions $\mathbf{4}$ and $\mathbf{5}$ exhibit similar behavior.

The heavy-atom skeleton is changed as a result of 1,2-migration of the amino group in the $\beta$-distonic ion formed by 1,5 -hydrogen transfer; this is discussed further below.

$$
\text { ר }
$$

1,6-Hydrogen abstraction leads for 5-8 to $\gamma$-distonic ions (eq 8 and 21). These do not undergo characteristic direct fragmentation reactions; indeed, there is no unambiguous evidence to show that they are other than short-lived intermediates when formed by isomerization of $\beta$-distonic ions. However, isomerization to $\gamma$-distonic species opens an additional reaction channel, namely isomerization of distonic ions to the corresponding amine molecular ions (eq 21). Reactions typical of the latter-in particular $\alpha$ cleavage, which for the deuteriated species in Table I leads predominantly to ions of $m / z 60$-are observed for ions with $N$-alkyl groups longer than ethyl $(5-8,12)$, that is, when formation of a $\gamma$-distonic ion is possible. By contrast, $\alpha$-cleavage (methyl loss) is not observed for $\mathbf{4 a}$, nor for $\mathbf{3}$ or $\mathbf{1 1}$. It seems that isomerization to conventional amine molecular ions requires at least a 5-membered cyclic transition state for intramolecular abstraction of the nitrogen-bonded hydrogen atom in order to compete with other low-energy reactions.

Confirmation of the occurrence of 1,4-hydrogen transfer from nitrogen to carbon comes from the reactions of $\gamma$-distonic ions formed by fragmentation of 3-alkoxypropylamines (18-20, eq 9). The MIKE and CID spectra of these $\gamma$-distonic ions are nearly identical with the spectra of the corresponding amine molecular ions (Table II).

$$
\begin{aligned}
& \widehat{\mathrm{N}}_{5}^{+} \widehat{\sim} \longrightarrow \widehat{\mathrm{N}}_{2}^{+} \widehat{\sim}_{2}^{-} \longrightarrow \\
& \widehat{\mathrm{NH}} \sim-\mathrm{CH}_{3} \mathrm{CH}_{2} \stackrel{+}{\mathrm{N} H}=\mathrm{CH}_{2}+\mathrm{C}_{2} \mathrm{H}_{5}
\end{aligned}
$$

Formation of $\gamma$-distonic ions by isomerization of long-chain $\beta$-distonic ions may be preceded by skeletal rearrangement1,2-migration of the protonated amino group after 1,5 -hydrogen abstraction - and the fragmentation of 6-8 shows that two different amine molecular ions are in fact formed. The MIKE spectrum of 8a (Figure 4a) illustrates that both processes are efficient; the two most intense peaks correspond to loss of $\mathrm{C}_{5} \mathrm{H}_{11}$. from ions with an intact hexyl group and loss of $\mathrm{C}_{4} \mathrm{H}_{9}{ }^{\circ}$ from ions with a 1 -methylpentyl group (eq 22).

Rearrangement to amine molecular ions is in some cases possible even for ions that do not, initially, possess $\gamma$-hydrogen atoms. The

(40) Burgers, P. C.; Holmes, J. L.; Terlouw, J. K. J. Chem. Soc., Chem. Commun. 1984, 642. 


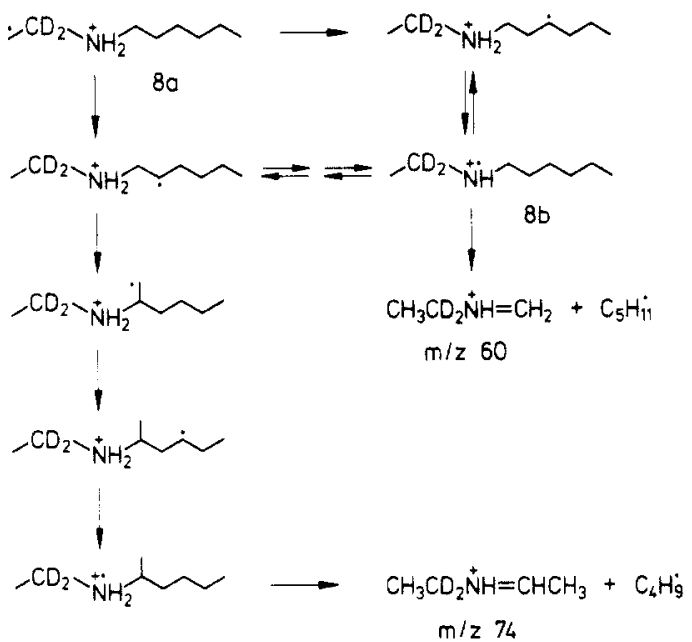

122

reactions leading to loss of $\mathrm{C}_{2} \mathrm{H}_{5}{ }^{\circ}$ from $9 \mathrm{a}$ (eq 16) and of $\mathrm{C}_{3} \mathrm{H}_{7}{ }^{\circ}$ from 10 illustrate that 1,2-migration of the protonated amino group can prepare the way for such isomerization reactions.

$C$-alkyl $\beta$-distonic ions show analogous behavior: the short-chain ions 13-16 do not isomerize to conventional amine molecular ions. In fact, no reactions common to the distonic and conventional radical cations are observed. The presence of longer alkyl chains (as in $\mathrm{C}_{2} \mathrm{H}_{5} \dot{\mathrm{C}} \mathrm{HCH}_{2} \mathrm{NH}_{3}{ }^{+}$(17)) makes 1,4-hydrogen abstraction possible, given that 1,2-migration of the amino group occurs. The predominant product ion, $\mathrm{CH}_{3} \mathrm{CH}=\mathrm{NH}_{2}{ }^{+}$, is formed by $\alpha$ cleavage of the intermediate sec-alkylamine molecular ion (eq 23).

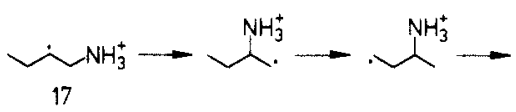

$$
\mathrm{NH}^{\mathrm{NH}_{2}^{+*}}-\mathrm{C}_{2} \mathrm{H}_{5}^{+}+\mathrm{CH}_{3} \mathrm{CH}=\mathrm{NH}_{2}^{+}
$$

Low-Energy Amine Molecular Ions React via Distonic Intermediates. The formation of amine molecular ions as intermediates prior to fragmentation of long-chain distonic amine ions does not demonstrate that the initial distonic ion population has to a large extent isomerized to ions of conventional structure. Isomerization to the latter occurs only en route to fragmentation. Most of the distonic ions examined in the present study are lower in energy than the corresponding amine molecular ions, ${ }^{41}$ and the collision-induced reactions of long-chain distonic ions include processes that are not observed for amine molecular ions, whereas the converse does not apply. Extensive isomerization to ions of conventional structure is not even observed for ${ }^{\circ} \mathrm{CH}_{2} \mathrm{CH}_{2}{ }^{+} \mathrm{NH}$ $\left(\mathrm{CH}_{3}\right) \mathrm{C}_{5} \mathrm{H}_{11}(\mathbf{1 2})$, although this ion is presumably less stable than the corresponding amine molecular ion. ${ }^{41}$ The latter reacts (spontaneously and upon collision) virtually exclusively by $\alpha$ cleavage, loss of $\mathrm{C}_{4} \mathrm{H}_{9}{ }^{\circ}$, whereas this reaction for 12 accounts for less than $40 \%$ of the fragment ion yield.

The only reaction observed for low-energy tertiary amines ${ }^{42}$ is in general $\alpha$-cleavage of the unrearranged molecular ion, whereas fragmentation is preceded by skeletal rearrangement for many

(41) Quantum chemical calculations ${ }^{21,24,25}$ have shown that many simple distonic amine radical cations have lower heats of formation than do the corresponding amine molecular ions. An estimate of the difference in heats of formation can be obtained from the hydrogen atom affinities (HA) of amine molecular ions and the bond dissociation energies (BDE) for aliphatic $\mathrm{C}-\mathrm{H}$ bonds. ${ }^{2}$ In general, primary amine molecular ions will be less stable than their distonic isomers, whereas tertiary amine molecular ions are expected to be more stable than their distonic counterparts; the energy difference should be small for secondary amine molecular ions and the corresponding distonic species. Approximate BDE and $\mathrm{HAs}$ are the following (in $\mathrm{kJ} / \mathrm{mol}$ ): $\mathrm{BDE}$ $\left(\mathrm{CH}_{2}\right)$ 400, $\mathrm{HA}\left(\mathrm{RNH}_{3}{ }^{\circ+}\right)$ 440, $\mathrm{HA}\left(\mathrm{R}_{2} \mathrm{NH}^{*+}\right)$ 400, $\mathrm{HA}\left(\mathrm{R}_{3} \mathrm{~N}^{\circ+}\right)$ 360. Aue, D. H.; Bowers, M. T. In Gas Phase Ion Chemistry; Bowers, M. T., Ed.; Academic Press: New York, 1979; Vol. 2, Chapter 9.

(42) Ingemann, S.; Hammerum, S.; Derrick, P. J. J. Am. Chem. Soc., following paper in this issue.
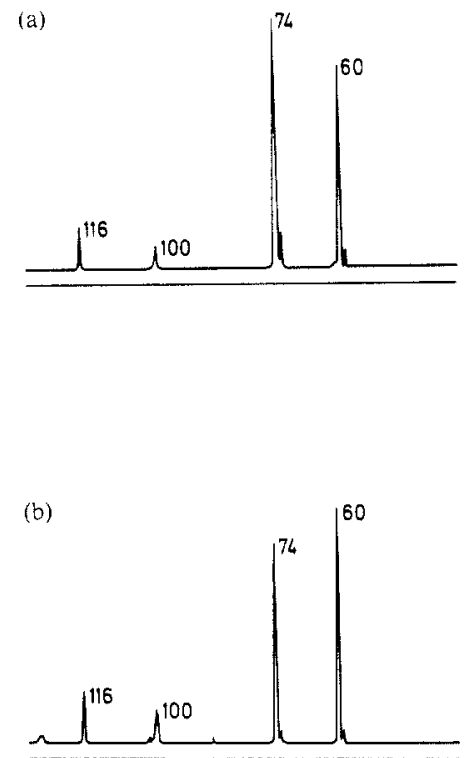

Figure 4. (a) MIKE spectrum of ${ }^{\circ} \mathrm{CH}_{2} \mathrm{CD}_{2}{ }^{+} \mathrm{NH}_{2} \mathrm{C}_{6} \mathrm{H}_{13}$ (8a). (b) MIKE spectrum of $\mathrm{CH}_{3} \mathrm{CD}_{2} \mathrm{NHC}_{6} \mathrm{H}_{13}{ }^{*+}(\mathbf{8 b})$.

long-chain primary and secondary amines. ${ }^{18,37,43,44}$ These rearrangements occur as a result of isomerization of amine molecular ions to distonic isomers. The intermediacy of $\alpha$ - and $\beta$-distonic species is particularly often encountered. The initial step is abstraction of an aliphatic hydrogen atom by the amino group. This occurs efficiently and reversibly for primary ${ }^{14,21,43,45}$ and secondary ${ }^{37,44}$ amines, whereas the hydrogen atom affinity of tertiary amine molecular ions is too low to make hydrogen abstraction a favorable reaction. ${ }^{41}$ Once formed by intramolecular hydrogen atom transfer, the distonic ions undergo rearrangement reactions - in particular hydrogen abstraction and 1,2-migration of the protonated amino group-as described above. The interconversion of conventional and distonic isomers, regardless of the initial structure of the reactant ions, is particularly obvious when the chain length permits intermediate formation of $\alpha$ - and $\beta$ distonic species. The MIKE spectra of ${ }^{\circ} \mathrm{CH}_{2} \mathrm{CD}_{2}{ }^{+} \mathrm{NH}_{2} \mathrm{C}_{6} \mathrm{H}_{13}$ (8a) and its conventional counterpart, $\mathrm{CH}_{3} \mathrm{CD}_{2} \mathrm{NHC}_{6} \mathrm{H}_{13}{ }^{\circ+}$, illustrate this point (Figure 4). The spectra are almost identical, differing slightly in peak intensities, which indicates that the same mixture of reacting ions is formed. In particular, the formation of abundant ions by loss of $\mathrm{C}_{4} \mathrm{H}_{9}{ }^{-}$from both precursors is a direct consequence of isomerization by 1,2-migration of the protonated amino group in a $\beta$-distonic intermediate (eq 22).

The intermediacy of $\alpha$-distonic isomers in the reactions of amine molecular ions is illustrated by the fragmentation of low-energy $\mathrm{N}$-isopropylpentylamine molecular ions, where the second most abundant product ion $(m / z 58)$ arises by direct loss of $\mathrm{C}_{5} \mathrm{H}_{11}{ }^{\circ}$. Cleavage of the $\mathrm{C}-\mathrm{N}$ bond is not commonly encountered for amine molecular ions, but it is a characteristic reaction of $\alpha$-distonic ions (see above). Deuterium labeling confirms that the reaction proceeds via an $\alpha$-distonic intermediate as shown in eq 24 ; the fragmentation of neither the $\alpha, \alpha$-dideuteriated nor the $\alpha^{\prime}$-deuterated analogues results in deuterium incorporation in the $\mathrm{m} / \mathrm{z}$ 58 product ion.

$$
\begin{aligned}
& \text { Y } \\
& \dot{Y}^{+} \mathrm{NH}_{2} \sim-\mathrm{F}_{\mathrm{NH}}^{+}+\mathrm{C}_{5} \mathrm{H}_{11} \\
& \mathrm{~m} / 258
\end{aligned}
$$

(43) Hammerum, S. Tetrahedron Lett. 1981, 22, 157. Audier, H. E.; Milliet, A.; Denhez, J. P. Org. Mass Spectrom. 1983, 18, 131.

(44) Sozzi, G. Thèse d'Etat, Universitê de Paris-Sud, Centre d'Orsay, 1984.

(45) Sozzi, G.; Denhez, J. P.; Audier, H. E.; Vulpius, T.: Hammerum, S. Tetrahedron Lett. 1985, 26, 3407 
Table I. MIKE Spectra of $N$ - and $C$-Alkyl $\beta$-Distonic Ions ${ }^{a}$

\begin{tabular}{|c|c|c|c|c|c|c|c|c|c|c|c|c|c|c|c|c|c|c|c|c|c|c|}
\hline & ion & $m / z$ & 116 & 102 & 100 & 88 & 86 & 74 & 73 & 72 & 60 & 59 & 58 & 48 & 47 & 46 & 45 & 44 & 31 & 30 & 18 & $b$ \\
\hline 3 & $\cdot \mathrm{CH}_{2} \mathrm{CH}_{2}{ }^{+} \mathrm{NH}_{2} \mathrm{CH}_{3}$ & 59 & & & & & & & & & & & & & & & & & 11 & 100 & & 90 \\
\hline $4 a^{c}$ & ${ }^{\circ} \mathrm{CH}_{2} \mathrm{CD}_{2}+\mathrm{NH}_{2} \mathrm{C}_{2} \mathrm{H}_{5}$ & 75 & & & & & & & & & & & & & 3 & 25 & 25 & $100^{d}$ & & & & 65 \\
\hline 5a & ${ }^{-} \mathrm{CH}_{2} \mathrm{CD}_{2}+\mathrm{NH}_{2} \mathrm{C}_{3} \mathrm{H}_{7}$ & 89 & & & & & & & & & 100 & 27 & $93^{e}$ & & 6 & 39 & 73 & & & & & 30 \\
\hline $6 \mathrm{a}^{\mathrm{c}}$ & ${ }^{-} \mathrm{CH}_{2} \mathrm{CD}_{2}+\mathrm{NH}_{2} \mathrm{C}_{4} \mathrm{H}_{9}$ & 103 & & & & 15 & & 27 & 10 & $10^{\prime}$ & 100 & 8 & & 15 & & 8 & 35 & & & & & 48 \\
\hline $7 \mathrm{a}^{\mathrm{c}}$ & ${ }^{\circ} \mathrm{CH}_{2} \mathrm{CD}_{2}^{+} \mathrm{NH}_{2} \mathrm{C}_{5} \mathrm{H}_{11}$ & 117 & & 10 & & & & 100 & & & 58 & 12 & & 10 & & & 8 & & & & & 50 \\
\hline $8 a^{c}$ & ${ }^{-} \mathrm{CH}_{2} \mathrm{CD}_{2}+\mathrm{NH}_{2} \mathrm{C}_{6} \mathrm{H}_{13}$ & 131 & 18 & & 98 & & & 100 & 9 & & 82 & & & & & & & & & & & 45 \\
\hline $9^{c}$ & ${ }^{\circ} \mathrm{CH}_{2} \mathrm{CH}_{2}^{+} \mathrm{NH}_{2} \mathrm{CH}\left(\mathrm{CH}_{3}\right)_{2}$ & 87 & & & & & & & & & & & $67^{h}$ & & & & & 100 & & & & 60 \\
\hline $9 \mathbf{a}^{c}$ & ${ }^{\circ} \mathrm{CH}_{2} \mathrm{CD}_{2}+\mathrm{NH}_{2} \mathrm{CH}\left(\mathrm{CH}_{3}\right)_{2}$ & 89 & & & & & & & & & 29 & 12 & $100^{i}$ & & 6 & 32 & 42 & & & & & 47 \\
\hline $10^{j}$ & ${ }^{-} \mathrm{CH}_{2} \mathrm{CH}_{2}{ }^{+} \mathrm{NH}_{2} \mathrm{C}\left(\mathrm{CH}_{3}\right)_{3}$ & 101 & & & & & 5 & & 11 & & & & 34 & & & & & 100 & & & & 67 \\
\hline $11^{c}$ & ${ }^{-} \mathrm{CH}_{2} \mathrm{CH}_{2}{ }^{+} \mathrm{NH}\left(\mathrm{CH}_{3}\right)_{2}$ & 73 & & & & & & & & & & & $(k)$ & & & & 100 & & & & & 95 \\
\hline $12^{c}$ & ${ }^{-} \mathrm{CH}_{2} \mathrm{CH}_{2}{ }^{+} \mathrm{NH}\left(\mathrm{CH}_{3}\right) \mathrm{C}_{5} \mathrm{H}_{11}$ & 129 & & & & & 26 & & & 100 & 27 & 68 & 12 & & & & & & & & & 43 \\
\hline $13^{l}$ & $\mathrm{CH}_{3}{ }^{2} \mathrm{CHCH}_{2} \mathrm{NH}_{3}{ }^{+}$ & 59 & & & & & & & & & & & & & & & & & & & 100 & 100 \\
\hline $14^{l}$ & ${ }^{\circ} \mathrm{CH}_{2} \mathrm{CH}\left(\mathrm{CH}_{3}\right) \mathrm{NH}_{3}^{+}$ & 59 & & & & & & & & & & & & & & & & & & & 100 & 100 \\
\hline $15^{\prime}$ & $\left(\mathrm{CH}_{3}\right)_{2} \mathrm{CCH}_{2} \mathrm{NH}_{3}^{+}$ & 73 & & & & & & & & & & & & & & & & & & & 100 & 100 \\
\hline $16^{\prime}$ & ${ }^{\circ} \mathrm{CH}_{2} \mathrm{C}\left(\mathrm{CH}_{3}\right)_{2} \mathrm{NH}_{3}{ }^{+}$ & 73 & & & & & & & & & & & & & & & & & & & 100 & 100 \\
\hline 17 & $\mathrm{C}_{2} \mathrm{H}_{5} \mathrm{C} \mathrm{CHCH}_{2} \mathrm{NH}_{3}^{+}$ & 73 & & & & & & & & & & & & & & & & 100 & & & 16 & 86 \\
\hline
\end{tabular}

${ }^{a}$ Relative abundance (from peak heights) of the major fragment ions in the MIKE spectra of ions 3-17. The corresponding 2-isopropoxyethylamines were used as precursors for ions 3-12, and the 2-benzyloxyethylamines for ions 13-16. 17 was formed from 2-ethylhexylamine (loss of $\mathrm{C}_{4} \mathrm{H}_{8}$ ). Ions carrying less than $3 \%$ of the total fragment ion current are omitted. ${ }^{b}$ Base peak intensity in $\%$ of total fragment ion current. ${ }^{c}$ The four most abundant fragment ion peaks in the CID spectra are the following $(\mathrm{m} / \mathrm{z}$ (\% rel abundance)): $\mathbf{4 a}, 47(31), 45(100), 44(35), 30(34)$. 6a, 73 (40), $60(100), 45(25), 30(24) .72,87(33), 74(53), 60(100), 30(24)$. 8a, $101(15), 74(44), 60(100), 30(12)$. 9, $59(49), 58(25), 45(28), 44(100)$. 9a, $59(80), 58(47), 47(62), 44(100) .11,57(5), 45(100), 44(12), 43(8) .12,101(22), 72(86), 59(100), 44(27) .{ }^{d} T_{0.5} \approx 11 \mathrm{~kJ} / \mathrm{mol} .{ }^{e} T_{0.5}$ $\approx 20 \mathrm{~kJ} / \mathrm{mol} .{ }^{f} T_{0.5} \approx 22 \mathrm{~kJ} / \mathrm{mol}$. ${ }^{8} T_{0.5} \approx 9 \mathrm{~kJ} / \mathrm{mol} .{ }^{h} T_{0.5} \approx 17 \mathrm{~kJ} / \mathrm{mol} .{ }^{i} T_{0.5} \approx 20 \mathrm{~kJ} / \mathrm{mol}$. ${ }^{j}$ The amino ether precursor could not be separated from the corresponding amide. The spectrum given was obtained by subtraction of the MIKE spectrum of $m / z 73$ formed from the pure amide from the MIKE spectrum of $\mathrm{m} / \mathrm{z} 73$ formed from a mixture of the precursor for 10 and the amide. The normalization of the spectra has been performed by assigning $\mathrm{m} / z$ 46 to the amide only; the peak intensities are hence only approximate. ${ }^{k}$ Loss of $\mathrm{CH}_{3}{ }^{*}$ is observed from 11 (5\% rel abundance) but not for the $-\mathrm{NH}\left(\mathrm{CD}_{3}\right)_{2}$ analogue. 'MIKE spectra measured after $12 \mathrm{eV}$ (nominal) ionization.

Table II. CID Spectra of $\gamma$-Distonic Ions and $C$-Alkyl $\beta$-Distonic Ions ${ }^{a}$

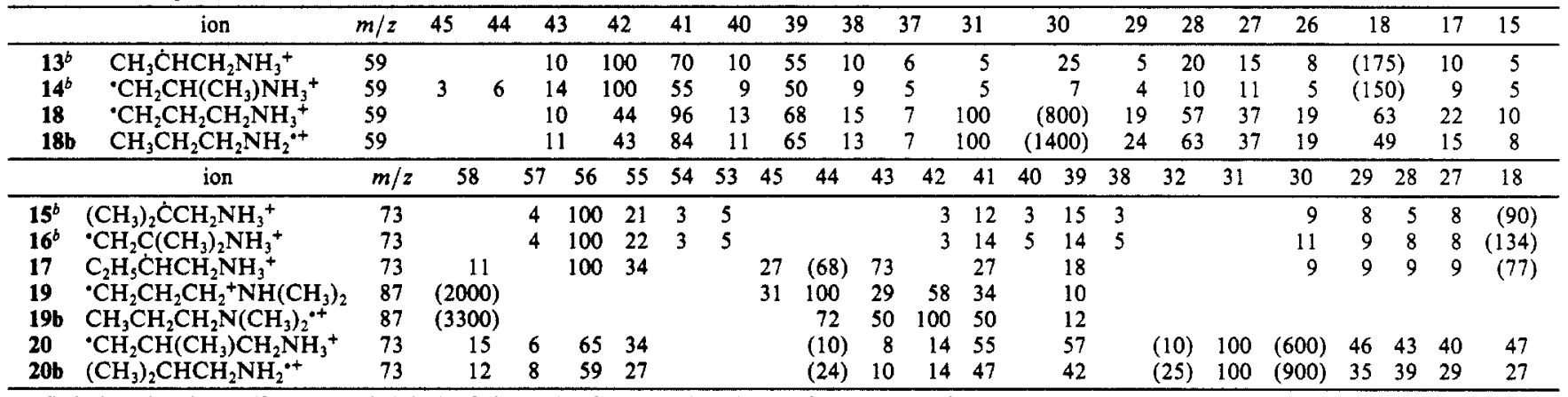

${ }^{a}$ Relative abundance (from peak heights) of the major fragment ions in the CID spectra of ions 13-20. Ions 13-16 are formed from the corresponding 2-benzyloxyethylamines, 17 from 2-ethylhexylamine (loss of $\mathrm{C}_{4} \mathrm{H}_{8}$ ), 18 and 20 from 3-benzyloxypropylamines, and 19 from $N, N$-dimethyl-3-isopropoxypropylamine. Signals which include contributions from spontaneous reactions are given in parentheses; these values have not been included in the normalization. Ions carrying less than $0.5 \%$ of the total fragment ion current are omitted. ${ }^{b} \mathrm{CID}$ spectra measured after $12 \mathrm{eV}$ (nominal) ionization.

\section{Conclusions}

Distonic ions are charged radicals. The characteristic reactions of distonic amine radical cations all involve the radical site directly, and the isomerization and fragmentation processes observed are closely related to well-described reactions of neutral radicals. ${ }^{46}$ This applies in particular to the reactions involving $\mathrm{C}-\mathrm{N}$ cleavage immediately adjacent to the radical site in $\alpha$ - and $\beta$-distonic ions, and to the intramolecular hydrogen atom abstraction with fivemembered or larger cyclic transition states. Further, 1,2-migration of a protonated amino group to a neighboring radical site has been established as a novel and general radical rearrangement, in many ways analogous to the well-known 1,2-migration of halogen atoms in $\beta$-substituted haloalkyl radicals. ${ }^{47}$ It may play a part in coenzyme $\beta_{12}$-induced rearrangements, and we expect that it will be observed also in other radical reactions in the condensed phase.

It has been suggested that some putative distonic ions should be considered, instead, as ion-molecule complexes, bonded primarily by electrostatic interactions. ${ }^{48}$ Our results do not support

(46) Green has advocated that the reactions of radical cations in general should be considered as radical reactions, the positive charge playing a subsidiary role. Green, M. M. Tetrahedron 1980, 36, 2687.

(47) Beckwith, A. L. J.; Ingold, K. U. In Rearrangements in Ground and Excited States; de Mayo, P., Ed.; Academic Press: New York, 1980; Vol. 1, Chapter 4. Skell, P. S.; Traynham, J. G. Acc. Chem. Res. 1984, 17, 160. this view for distonic amine ions. Consensus seems not to have been reached with regard to the predictions that can be derived from models involving intermediate ion-molecule complexes, nor have unambiguous criteria to establish the intermediacy of such complexes been proposed. However, neither the existence of an appreciable barrier to $1,2-\mathrm{NH}_{3}$ migration in $\mathbf{1 4}$ nor the specific $\gamma$-hydrogen transfer in 15 would seem compatible with description of $\beta$-distonic ions as alkene radical cations loosely bonded to amines. This is in agreement with computational results ${ }^{25}$ for ion 2, which predict a "normal" $\mathrm{C}-\mathrm{N}$ bond length $(1.53 \AA)$ and a substantial barrier to the $1,2-\mathrm{NH}_{3}$ migration $(120 \mathrm{~kJ} / \mathrm{mol})$. The heat of formation calculated for 2 lies considerably below that estimated for $\mathrm{a}\left[\mathrm{C}_{2} \mathrm{H}_{4}+\mathrm{NH}_{3}\right]^{\circ+}$ complex bonded only by electrostatic interactions between alkene and ammonia.

Finally, our results show that only distonic amine ions with long alkyl substituents isomerize below the threshold for decomposition to the corresponding amine molecular ions. Isomerization is reversible, and the low-energy fragmentations of many amine molecular ions in fact turn out to be reactions of the distonic isomers. This observation extends to other aliphatic radical cations. Distonic counterparts of the molecular ions are frequently readily

(48) Postma, R.; Ruttink, P. J. A.; Terlouw, J. K.; Holmes, J. L. J. Chem. Soc., Chem. Commun. 1986, 683. Terlouw, J. K.; Heerma, W.; Burgers, P. C.; Holmes, J. L. Can. J. Chem. 1984, 62, 289. 
accessible and of comparable stability. One important reason for the difference often observed between the reactions in the ion source and the reactions of metastable ions is that distonic ions, as stable forms or as reactions intermediates, are prominent among the long-lived, low-energy ion population.

Acknowledgment. The encouragement and support from Prof. Dr. H.-Fr. Grützmacher and the expert technical assistance from Mr. E. Gärtner are gratefully acknowledged.

Registry No. 3, 114377-13-8; 4a, 114377-14-9; 5a, 114377-15-0; 6a, $114377-16-1 ; 7 \mathbf{a}, 114377-17-2 ; 8 \mathbf{a}, 114377-18-3 ; 9,114377-19-4 ; 9 \mathbf{a}$, $114377-20-7 ; 10,114377-21-8 ; 11,114377-22-9 ; 12,114377-23-0 ; 13$, $53925-78-3 ; 14,20694-03-5 ; 15,20694-06-8 ; 16,114377-24-1 ; 17$,
114377-25-2; 18, 20694-02-4; 18b, 70677-54-2; 19,70677-54-2; 19b, 114377-27-4; 20, 20694-07-9; 20b, 99033-68-8; $i$-PrO $\left(\mathrm{CH}_{2}\right)_{2} \mathrm{NHCH}_{3}$, 114377-28-5; i-PrOCH${ }_{2} \mathrm{CD}_{2} \mathrm{NHC}_{2} \mathrm{H}_{5}, \quad 114377-29-6 ; \quad i$ $\mathrm{PrOCH}_{2} \mathrm{CH}_{2} \mathrm{CD}_{2} \mathrm{NHC}_{3} \mathrm{H}_{7}$, 114377-30-9; i- $\mathrm{PrOCH}_{2} \mathrm{CD}_{2} \mathrm{NHC}_{4} \mathrm{H}_{9}$, $114377-31-0 ; \quad i-\mathrm{PrOCH}_{2} \mathrm{CD}_{2} \mathrm{NHC}_{5} \mathrm{H}_{11}, \quad 114377-32-1 ; i-$ $\mathrm{PrOCH}_{2} \mathrm{CD}_{2} \mathrm{NHC}_{6} \mathrm{H}_{13}, 114377-33-2 ; i-\mathrm{PrO}\left(\mathrm{CH}_{2}\right) \mathrm{NHCH}\left(\mathrm{CH}_{3}\right)_{2}$, 114377-34-3; $i$-PrOCH${ }_{2} \mathrm{CD}_{2} \mathrm{NHCH}\left(\mathrm{CH}_{3}\right)_{2}, 114377-35-4 ; i$-PrO$\left(\mathrm{CH}_{2}\right)_{2} \mathrm{NHC}\left(\mathrm{CH}_{3}\right)_{3}, 114377-36-5 ; i-\operatorname{PrO}\left(\mathrm{CH}_{2}\right)_{2} \mathrm{~N}\left(\mathrm{CH}_{3}\right)_{2}, 71126-59-5$; i- $\mathrm{PrO}\left(\mathrm{CH}_{2}\right)_{2} \mathrm{~N}\left(\mathrm{CH}_{3}\right) \mathrm{C}_{5} \mathrm{H}_{11}, 114377-37-6 ; \mathrm{PhCH}_{2} \mathrm{OCH}\left(\mathrm{CH}_{3}\right) \mathrm{CH}_{2} \mathrm{NH}_{2}$, 6449-46-3; $\mathrm{PhCH}_{2} \mathrm{OCH}_{2} \mathrm{CH}\left(\mathrm{CH}_{3}\right) \mathrm{NH}_{2}, 114377-38-7$; $\mathrm{PhCH}_{2} \mathrm{OC}-$ $\left(\mathrm{CH}_{3}\right)_{2} \mathrm{CH}_{2} \mathrm{NH}_{2}, 114377$-39-8; $\mathrm{PhCH}_{2} \mathrm{OCH}_{2} \mathrm{C}\left(\mathrm{CH}_{3}\right)_{2} \mathrm{NH}_{2}, 114377-40-$ 1: $\mathrm{CH}_{3}\left(\mathrm{CH}_{2}\right)_{4} \mathrm{CH}\left(\mathrm{NH}_{2}\right) \mathrm{CH}_{2} \mathrm{CH}_{3}, 24552-04-3 ; \mathrm{PhCH}_{2} \mathrm{O}\left(\mathrm{CH}_{2}\right)_{3} \mathrm{NH}_{2}$, 16728-64-6; $\operatorname{PrNH} 2,107-10-8$; $i-\mathrm{PrO}\left(\mathrm{CH}_{2}\right)_{3} \mathrm{~N}_{2}\left(\mathrm{CH}_{3}\right)_{2}, 71126-66-4$; $\mathrm{PrNMe}_{2}, 926-63-6 ; \mathrm{PhCH}_{2} \mathrm{OCH}_{2} \mathrm{CH}\left(\mathrm{CH}_{3}\right) \mathrm{CH}_{2} \mathrm{NH}_{2}, 114377-41-2$; $\left(\mathrm{CH}_{3}\right)_{2} \mathrm{CHCH}_{2} \mathrm{NH}_{2}, 78-81-9$.

\title{
Secondary Hydrogen Isotope Effects on Simple Cleavage Reactions in the Gas Phase: The $\alpha$-Cleavage of Tertiary Amine Cation Radicals
}

\author{
Steen Ingemann, ${ }^{*}$ Steen Hammerum, ${ }^{*, *}$ and Peter J. Derrick ${ }^{\dagger}$ \\ Contribution from the Department of General and Organic Chemistry, University of Copenhagen, \\ The H. C. Ørsted Institute, DK-2100 Copenhagen $\oslash$, Denmark, and the School of Chemistry, \\ University of New South Wales, P.O. Box 1, Kensington, NSW 2033, Australia. \\ Received November 27, 1987
}

\begin{abstract}
Intramolecular secondary hydrogen isotope effects on the $\alpha$-cleavage reaction of 14 unsymmetrically deuterium labeled tertiary amine cation radicals have been determined in order to probe the variation of the isotope effect with the distance to the rupturing carbon-carbon bond, with the structure of the radical lost, and with the internal energy of the reactant. The low-energy molecular ions exhibit normal isotope effects (i.e., predominant loss of the unlabeled alkyl radical), which are highest for $\beta$-labeled ions ( 1.30 per deuterium) and decrease with increasing distance between the isotopic label and the point of rupture; significant effects are observed even for deuterium substitution four bonds removed (1.04 per deuterium for $\epsilon$-labeled ions). The isotope effects are relatively small and normal for molecular ions with high internal energy, with one exception: the secondary isotope effect on the fast (ion-source) reactions of the $\delta$-labeled $N$-methyldipentylamine is inverse ( 0.98 per deuterium). The structure of the alkyl radical lost seems not to have a pronounced influence on the secondary isotope effects.
\end{abstract}

Isotope effects are often encountered in studies of the reactions of gaseous positive ions. ${ }^{1,2}$ Structural and mechanistic information has in most instances been derived from the observation of primary hydrogen isotope effects; conclusions have, in some cases, been based on the (implicit) premise that secondary isotope effects are generally relatively small and can be neglected. This may often not be a valid assumption, given that appreciable secondary isotope effects have been reported in a number of instances. ${ }^{1,-15}$ In particular, relatively large intramolecular secondary isotope effects have been described for loss of methyl radicals from the molecular ions of alkylbenzenes, 5,15 for elimination of methane from the propane and 2-methylpropane cation radicals, ${ }^{13}$ and for elimination of methane from tert-butoxide ions in the gas phase. ${ }^{14}$

Isotope labeling influences the rates of the reactions of cation radicals, in many cases through a combination of primary and secondary isotope effects. Mechanistic conclusions often depend on the ability to distinguish between the relative contributions from primary and secondary effects, but a quantitative distinction can be difficult; even qualitative estimates can be difficult to make, in the absence of systematic experimental studies of secondary hydrogen isotope effects. We have therefore investigated the influence of deuterium substitution on simple cleavage reactions of cation radicals, to determine the variation of secondary hydrogen

\footnotetext{
University of Copenhagen.
+Present address: Department of Chemistry, University of Warwick, Coventry CV4 7AL, U.K
}

isotope effects with the distance to the bond cleavage, with the structure of the alkyl radical lost, and with the internal energy

(1) Derrick, P. J.; Donchi, K. F. In Comprehensive Chemical Kinetics; Bamford, C. H., Tipper, C. F. H., Eds.; Elsevier: Amsterdam, 1981; Vol. 24, pp 53-247. (b) Derrick, P. J. In Current Topics in Mass Spectrometry and Chemical Kinetics; Beynon, J. H., McGlashan, M. L., Eds.; Heyden \& Sons Ltd.: London, 1982; pp 61-67. (c) Derrick, P. J. Mass Spectrom. Rev. 1983, 2, 285-298.

(2) Levsen, K. Fundamental Aspects of Organic Mass Spectrometry; Verlag Chemie: Weinheim, 1978.

(3) Shapiro, R. H.; McEntee, T. E.; Coffen, D. L. Tetrahedron 1968, 24, 2809-2815

(4) McLafferty, F. W.; McAdoo, D. J.; Smith, J. S.; Kornfeld, R. J. Am. Chem. Soc. 1971, 93, 3720-3730.

(5) Neeter, R.; Nibbering, N. M. M. Org. Mass Spectrom. 1973, 7, 1091-1101.

(6) Smith, R. D.; Futrell, J. H. Org. Mass Spectrom. 1976, 11, 309-312.

(7) Eadon, G.; Zawalski, R. Org. Mass Spectrom. 1977, 12, 599-605.

(8) Jones, G., II; McDonnell-Bushnell, L. P. J. Org. Chem. 1978, 43, 2184-2189

(9) Broer, W. J.; Weringa, W. D. Org. Mass Spectrom. 1979, 14, 36-45. (10) (a) Mruzek, M.; Bouchoux, G. Int. J. Mass Spectrom. Ion Phys. 1980, 33, 301-311. (b) Bouchoux, G.; Mruzek, M. Adv. Mass Spectrom. $1980,8,90-96$

(11) Baer, T.; Kary, R. Chem. Phys. Lett. 1982, 92, 659-662.

(12) Ingemann, S.; Hammerum, S. Adv. Mass Spectrom. 1980, 8 $647-650$.

(13) (a) Mead, P. T.; Donchi, K. F.; Traeger, J. C.; Christie, J. R.; Derrick, P. J.J.Am. Chem. Soc. 1980, 102, 3364-3369. (b) Donchi, K. F.; Brownlee, R. T. C.; Derrick, P. J. J. Chem. Soc., Chem. Commun. 1980, 1061-1062. 